\title{
WASIAT WAJIBAH DAN IMPLEMENTASINYA TERHADAP HUKUM KELUARGA DI INDONESIA
}

\author{
Syahrul Mubarak Subeitan *
}

\begin{abstract}
Wasiat wajibah is a study in family law in Indonesia that provides opportunities for the adopted children and adoptive parents to inherit. This is stated in Kompilasi Hukum Islam (KHI) in Article 209. Although Indonesia has only recently carried out a family law reforms regarding Wasiat Wajibah compared to other Muslim countries, reform of family law in Indonesia cannot be separated from the meaning and nuances of Islamic law. This article reviews the concept of Wasiat Wajibah in Indonesia, then it is implemented with issues that occur around the community to obtain the relevance in accordance with the changing times.
\end{abstract}

Keywords: Wasiat Wajibah, Family Law, Kompilasi Hukum Islam. 


\section{A. Pendahuluan}

Kondisi masyarakat mengalami perubahan yang sangat cepat. Perubahan tersebut menimbulkan beberapa masalah yang menuntut untuk segera diselesaikan. Hal ini harus diakui bahwa dalam mencari sebuah solusi harus mempertimbangkan berbagai aspek sehingga tidak jarang hampir semua pakar dari berbagai bidang keilmuan ikut terjun dalam rangka menemukan solusinya. Di antara masalah yang paling urgen di masyarakat adalah masalah kewarisan dan wasiat.

Masalah kewarisan dan wasiat ini dalam beberapa Negara telah mengalami rekonstruksi dalam pembaruan hukum keluarga guna menjawab realitas pada masyarakat sekarang. Mesir, di antara beberapa Negara yang melakukan rekonstruksi dan reformasi terhadap hukumnya. Di antara reformasi yang dilakukan Mesir adalah mengenai masalah wasiat dengan mengundangkan wasiat wajibah dalam Undang-Undang Nomor 71 Tahun 1946 tentang Hukum Wasiat. Kemudian konsep wasiat wajibah di Mesir tersebut diadopsi oleh sebagian negara muslim di dunia.

Wasiat wajibah sendiri merupakan bentuk wasiat yang pelaksanaannya tidak dipengaruhi atau tidak tergantung kepada kemauan atau kehendak si mayyit, namun wasiat ini tetap dilaksanakan, baik diucapkan atau tidak diucapkan, baik dikehendaki maupun tidak dikehendaki oleh si mayyit. ${ }^{1}$ Oleh karena itu, di beberapa Negara muslim memberikan solusi untuk masalah tersebut dengan pemberian wasiat wajibah.

Berbeda dengan konsep wasiat wajibah pada umumnya di sejumlah negara, Indonesia mengalami perubahan makna dan nuansa, yaitu hanya diberikan kepada anak angkat atau orang tua angkat yang mana telah diatur oleh Kompilasi Hukum Islam -untuk selanjutnya disebut dengan KHI-. ${ }^{2}$ Hal tersebut dikarenakan hubungan nasab

1 Suparman Usman dan Yusuf Somawinata, Fiqih Mawaris Hukum Kewarisan Islam, (Jakarta: Gaya Media Pratama, 1997), hlm. 163.

2 Ahmad Rofiq, Hukum Islam di Indonesia, (Jakarta; PT RajaGrafindo Persada, 1997), hlm. 447. 
merupakan penentu seseorang menjadi ahli waris atau bukan. Namun tak luput dari pranata sosial di masyarakat bahwa sebagian dari masyarakat melakukan pengangkatan anak. Pengangkatan anak ternyata tidak hanya menimbulkan akibat sosial, seperti ikatan emosional dan kasih sayang yang menghilangkan sebagian dari rasa sayang terhadap anak biologisnya. Akan tetapi akibat lanjutannya adalah timbulnya pengakuan orang tua angkat terhadap hak anak angkat atas harta peninggalannya, yang kemudian berujung pada pemeliharaan harta kekayaan (harta warisan) baik dari orang tua angkat maupun orang tua asal (kandung).

Dari permasalah di atas, maka penulis tertarik untuk mengkaji kembali konsep wasiat wajibah di Indonesia, kemudian diimplementasikan dengan isu yang terjadi di sekitar masyarakat dan pada akhirnya untuk mendapatkan suatu relevansi yang sesuai dengan perubahan zaman.

\section{B. Pembahasan.}

\section{Pengertian dan Dasar Hukum Wasiat Wajibah dalam Hukum Keluarga Indonesia}

Dalam Kamus Besar Bahasa Indonesia, wasiat wajibah dapat dilihat dari segi bahasa terdiri dari dua suku kata, kata "Wasiat" berarti sesuatu pesan terakhir yang disampaikan oleh orang yang akan meninggal dunia dan biasanya berkenaan dengan harta kekayaan dan sebagainya. Wasiat juga berarti sesuatu pesan yang dibuat sendiri, tidak di depan Notaris, yang membuat penunjukan seseorang dalam waris untuk menerima sebagian atau seluruh warisan. Sedangkan "Wajib" berarti sesuatu yang harus dilakukan, tidak boleh tidak harus dilaksanakan. ${ }^{3}$ Jadi, wasiat wajibah merupakan suatu pemberian berupa harta kekayaan atau barang berharga lainnya yang wajib diberikan kepada si penerima wasiat.

3 Departemen Pendidikan dan Kebudayaan, Karnus Besar Bahasa Indonesia, Cet. 2, (Jakarta : Balai Pustaka,1989), hlm. 1006-9. 
Dalam pengertian lain, wasiat wajibah merupakan tindakan yang dilakukan penguasa atau hakim sebagai aparat negara untuk memaksa atau memberi putusan wajib wasiat bagi orang yang telah meninggal dunia, yang diberikan kepada orang tertentu dalam keadaan tertentu pula. ${ }^{4}$ Dalam versi ini dikemukakan bahwa wasiat wajibah adalah wasiat yang dipandang sebagai telah dilakukan oleh seseorang yang akan meninggal dunia, walaupun sebenarnya ia tidak ada meninggalkan wasiat tersebut. Hal ini yang membedakan antara wasiat wajibah dan wasiat pada umumnya. Adapun wasiat pada umumnya merupakan wasiat yang dilakukan oleh seorang pewasiat secara sukarela "tabarru", kepada orang lain atau keluarganya ${ }^{5}$

Terkait dengan pengertian wasiat pada umumnya di atas, terdapat beberapa ayat yang menyatakan ketentuan tentang wasiat pada umumnya ini, diantaranya adalah pada QS. an-Nisa' [4]: 11 dan 12, kemudian dalam QS. al-Ma'idah [5]: 106. Tiga ayat ini menjelaskan bahwa wasiat yang diakadkan oleh pemilik harta sebagai suatu yang bersifat kebolehan (ibahah). Hal ini berbeda dengan wasiat wajibah yang bersifat wajib, sehingga ketika pemilik harta tidak berwasiat, maka wasiat dianggap tetap berlaku dan bisa dilaksanakan berdasarkan putusan pengadilan. ${ }^{6}$

Di Indonesia, wasiat wajibah diutamakan untuk anak angkat dan atau orang tua angkat. Hal ini secara tegas dinyatakan dalam $\mathrm{KHI}^{7}$ pada pasal 209 dan menjadi dasar hukum eksistensi wasiat

${ }^{4}$ Chairumman Pasaribu dan Suhrawardi K. Lubis, Hukum Perjanjian dalam Islam, (Jakarta: Sinar Grafika, 1996), hlm. 130.

5 Samsul Hadi, "Pembatasan Wasiat Sebagai Bentuk Keadilan Hukum Islam”, Al-Ahwal: Jurnal Hukum Keluarga Islam, UIN Sunan Kalijaga, Vol. 9, No. 2, Desember 2016 M/1438 H, hlm. 173.

${ }^{6}$ Ibid., hlm. 173-4.

${ }^{7}$ Kompilasi Hukum Islam dibentuk karena melihat peradilan sudah berusia sangat lama sedangkan hakimnya tidak memiliki buku standar yang menjadi rujukan bersama seperti KUHP. Ini berakibat bahwa jika para hakim menerima kasus yang harus diadili maka yang menjadi rujukannya adalah beberapa buku fiqih secara langsung tanpa sesuatu standarisasi atau keseragaman. Akibat lanjutannya, secara praktis terhadap kasus-kasus yang sama dapat lahir putusan yang berbeda jika ditangani oleh hakim yang berbeda. Lihat Munawir Sadzali, Peradilan Agama dan 
wajibah dalam sistem hukum kewarisan Islam di Indonesia. Adapun bunyi pasal 209 dalam KHI adalah: ${ }^{8}$

(1) Harta peninggalan anak angkat dibagi berdasarkan pasal-pasal 176 sampai dengan 193 tersebut diatas, sedangkan terhadap orang tua angkat yang tidak menerima wasiat diberi wasiat wajibah sebanyak-banyaknya $1 / 3$ dari warisan anak angkatnya.

(2) Terhadap anak angkat yang tidak menerima wasiat diberi wasiat wajibah sebanyak-banyaknya $1 / 3$ dari harta warisan orang tua angkatnya.

Adapun substansi dari wasiat wajibah dalam pasal tersebut, menurut Ahmad Rofiq dalam bukunya "Hukum Islam di Indonesia" adalah suatu tindakan yang dilakukan oleh penguasa atau hakim sebagai aparat negara untuk memaksa, atau memberi putusan wajib wasiat bagi orang yang telah meninggal, yang diberikan kepada orang tertentu dan dalam keadaan tertentu. ${ }^{9}$ Menurut hukum, wasiat wajibah bermakna seseorang dianggap telah menerima wasiat meskipun tidak ada wasiat secara nyata (in cocreto). Anggapan hukum itu lahir dari asas apabila dalam suatu hal hukum telah menetapkan wajib berwasiat, maka ada atau tidak ada wasiat dibuat, wasiat itu dianggap ada dengan sendirinya. ${ }^{10}$

Ketentuan pasal $209 \mathrm{KHI}$ ini merupakan suatu terobosan baru, yang didasarkan kepada suatu kenyataan bahwa tindakan pengangkatan anak (adopsi) merupakan suatu kebiasaan yang terjadi di dalam kehidupan masyarakat Islam, meskipun hal itu tidak dengan sendirinya terjadi hubungan hukum antara anak angkatnya dengan orang tua angkatnya. Anak angkat tetap memiliki hubungan hukum

Kompilasi Hukum Islam dalam tata hukum Indonesia, (Yogyakarta: UII Press, 1993), hlm, 2.

8 Tim Redaksi Nuansa Aulia, Kompilasi Hukum Islam, (Bandung: CV. Nuansa Aulia, 2009), hlm. 65.

${ }^{9}$ Ahmad Rofiq, Hukum Islam ....., hlm. 462.

${ }^{10}$ Cik Hasan Bisri, Kompilasi Hukum Islam dan peradilan Agama dalam Sistem Hukum Nasional, (Jakarta: Logos Wacana Ilmu, 1999), hlm. 2-3. 
dengan orang tua kandungnya. ${ }^{11}$ Berdasarkan kenyataan, hubungan sosial antara anak angkat dengan orang tua angkat yang demikianlah melahirkan ketentuan tentang wasiat wajibah, inilah ketentuan hukum Islam khas Indonesia. ${ }^{12}$

Walaupun demikian, menurut Raihan A. Rasyid bahwa keberadaan pasal 209 tersebut dinilai kontroversial di kalangan ahli hukum Islam, praktisi hukum dan pencari keadilan. Karena pasal tersebut belum jelas dan tanpa penjelasan, sehingga tidak dapat dimengerti apa maksudnya sehingga pasal tersebut belum dapat dipedomani untuk diterapkan. ${ }^{13}$ Hal yang sama diutrakan oleh Ahmad Rofiq, bahwa tidak diketahui secara pasti asal usul penetapan pasal tersebut, mengapa anak angkat atau orang tua angkat diberi wasiat wajibah. ${ }^{14}$

KHI membuat ketentuan sendiri, dengan membatasi orang yang berhak menerima wasiat wajibah adalah anak angkat atau orang tua angkat saja, pertimbangannya adalah KHI telah mengintrodusir konsep penggantian kedudukan atau waris pengganti yang dalam istilah BW disebut platsvervulling. ${ }^{15}$

\section{Wasiat Wajibah dalam Substansi Hukum Islam}

Wasiat wajibah seperti pada pengertian di atas adalah wasiat yang pelaksanaannya tidak dipengaruhi atau tidak tergantung kepada kemauan atau kehendak si pemberi wasiat. Ketentuan tersebut merupakan hasil ijtihad para ulama dalam menafsirkan QS. alBaqarah\{[2]: 180:

${ }^{11}$ Ibid., hlm. 14.

12 Syukri Abu Bakar, "Aplikasi 'Urf dalam Kompilasi Hukum Islam", Istinba>th: Jurnal Hukum Islam, UIN Mataram, Vol. I, No. 1, Juli-Desember 2003, hlm. 90 .

\footnotetext{
${ }^{13}$ Cik Hasan Bisri, Kompilasi Hukum Islam....., hlm. 82.

${ }^{14}$ Ahmad Rofiq, Hukum Islam ....., hlm. 463.

${ }^{15}$ Ibid.
} 


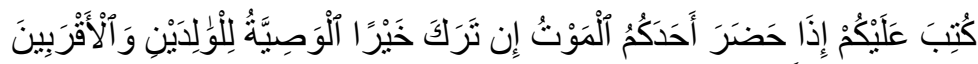

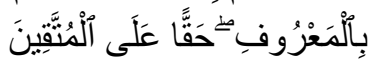

"Diwajibkan atas kamu, apabila seorang di antara kamu kedatangan (tanda-tanda) maut, jika ia meninggalkan harta yang banyak, Berwasiat untuk ibu-bapak dan karib kerabatnya secara ma'ruf, (ini adalah) kewajiban atas orang-orang yang bertakwa."

Terkait tafsir ayat tersebut, sebagian ulama berpendapat bahwa wasiat kepada ibu-bapak dan kerabat (walidayn dan aqrabin) yang mendapat bagian harta warisan dapat diterapkan dan dilaksanakan. Sementara sebagian ulama lain, berpendapat bahwa ketentuan wasiat wajibah tidak dapat diterapkan dan dilaksanakan karena ketetapan mengenai wasiat wajibah dalam ayat tersebut sudah di-nasakh ${ }^{16}$ atau diganti, baik oleh ayat-ayat Al-Qur'an yang mengatur masalah kewarisan ${ }^{17}$ maupun Hadis Nabi saw. yang menyatakan dalam HR. At-Tirmizy:

$$
\text { إنّ الله قد أعطى كلّ ذي حقّ حقّه فلا وصيّة لو ارث } 18
$$

"Sesungguhnya Allah telah memberikan setiap orang masing-masing haknya, maka tidak boleh harta itu diwasiatkan kepada ahli waris".

كُ كتب " Jumhur mufassirin menyatakan bahwa yang dimaksud "فرض عليكم" yang artinya: "diwajibkan kepada kamu", tetapi pada akhir ayat tersebut dijelaskan bahwa kewajiban tersebut ditujukan hanya kepada orang-orang yang bertakwa saja ( حقا على (الدتقين), sehingga ini menunjukkan bahwa hukum wasiat tidaklah

${ }^{16}$ Hasanayn Muhammad Makhluf, al-Mawaris fi al-Syari 'ah al-Islamiyyah, (Mesir: Mathba'ah al-Mudna, 1976), hlm. 17.

${ }^{17}$ Lihat QS. An-Nisa' [4]: 11-12.

18 Muhammad Nasiruddin al-Bani, Șahīh Sunan at-Tirmiż̄i, CD, Bab "Wașiat", hadis no: 2210. 
wajib. Karena seandainya diwajibkan tentu ditujukan kepada semua umat Islam dengan menggunakan kata-kata "حقا على المسلمين."

Implikasi wasiat yang dipahami oleh para ahli hukum Islam itu adalah kewajiban wasiat hanya dipenuhi jika seseorang telah berwasiat secara nyata, jika mereka tidak berwasiat maka tidak perlu mengada-ada agar wasiat dilaksanakan karena ketentuan yang tersebut dalam QS. Al-Baqarah\{ [2]: 180 itu telah di-nasakh oleh QS. AnNisa' [4]: 11-12. Oleh karena itu, kedua orang tua dan kerabat dekatnya, baik yang menerima warisan maupun yang tidak menerima warisan setelah turunnya surat An-Nisa' [4]: 11-12 itu sudah tertutup haknya untuk menerima wasiat. $^{20}$

Berdasarkan penjelasan tersebut, dapat disimpulkan bahwa hukum berwasiat tidaklah wajib, bahkan wasiat untuk orang yang telah dinyatakan sebagai ahli waris hukumnya tidak boleh, kecuali atas persetujuan dari ahli waris yang lain. Pendapat inilah yang dianut oleh mayoritas ulama klasik, terutama empat imam mazhab.

Berbeda dengan pendapat di atas, sebagian dari kalangan ahli hukum madzhab Hambali memiliki kriteria tersendiri dalam hukum wasiat ini, dijelaskan bahwa wasiat menjadi "wajib" apabila wasiat tersebut jika tidak dilakukan akan membawa akibat hilangnya hak-hak atau peribadatan. Seperti diwajibkan bagi orang yang menanggung kewajiban zakat, haji atau kifarat ataupun nazar. Wasiat menjadi "sunnah" jika berwasiat kepada kerabat yang fakir dan tidak bisa mewaris, dengan syarat orang yang meninggal dunia meninggalkan harta yang banyak dan tidak melebihi sepertiga harta. Wasiat menjadi "makruh" jika wasiat dilaksanakan oleh orang yang tidak meninggalkan harta yang cukup, sedangkan ia mempunyai ahli waris yang membutuhkannya. Wasiat menjadi "haram" jika wasiat dilaksanakan melebihi sepertiga harta yang dimilikinya, atau berwasiat kepada orang yang berburu harta dan merusak. Wasiat

${ }^{19}$ Ibn 'Arabi, Ahkam al-Qur'an, Juz I, (Bairut: Dar al-Kutub al-'Ilmiyyah, 1988), hlm. 104.

${ }^{20}$ Ahmad Rofiq, Hukum Waris....., hlm. 446. 
menjadi "mubah" apabila dilaksanakan tidak sesuai dengan petunjuk syar'i seperti wasiat kepada orang yang kaya. ${ }^{21}$

Selain pendapat di atas, terdapat beberapa pendapat dari ahli fiqh, seperti Adh-Dhahiri, At-Thobari, Ibnu Hazm, dan Abu Bakar bin Abdil 'Aziz dari ulama' madzhab Hambali mengatakan bahwa wasiat adalah kewajiban agama dan pembayaran kewajiban bagi kedua orang tua dan para kerabat yang tidak dapat karena terhalang dari mewarisi. $^{22}$

Ibnu Hazm, sebagai seorang pencetus wasiat wajibah menegaskan bahwa wasiat bagi ahli waris yang tidak berhak menerima warisan hukumnya wajib, bahkan wasiat kepada ibu, bapak, dan karib kerabat yang tidak mewarisi hukumnya fardhu, baik karena perbedaan agama, perbudakan, atau karena ada ahli waris lain yang menghijabnya. ${ }^{23}$

Adapun dasar hukum yang menjadi rujukan para ulama terkait wajib wasiat kepada kedua orang tua dan karib kerabat yaitu: Pertama, bahwa seluruh ayat Al-Qu'ran adalah muhkamat, artinya tidak ada nasikh-mansukh dalam Al-Qur'an. Jadi ayat 180 surah alBaqarah tentang wasiat tersebut tidak di-nasakh (dihapus atau dihilangkan hukumnya, baik oleh ayat-ayat (mawaris) Al-Qur'an maupun Hadis. Kedua, firman Allah swt. dalam surah al-Baqarah ayat 180, menurut Ibnu Hazm mempunyai dalalah (tunjukan) yang qath'y (pasti dan tidak beralternatif makna), yakni wajib hukumnya berwasiat terhadap kedua orang tua dan karib kerabatnya bagi setiap orang yang memiliki harta yang banyak sebelum meninggal dunia. ${ }^{24}$ Ketiga,

${ }^{21}$ Abdurrahman Al-Jaziri, al-Fiqhu 'Ala Mazahib al-Arba'ah, terj. Moh. Zukri, Jilid 4, (Semarang: Asy-Syifa', 1994), hlm. 327.

${ }^{22}$ Wahbah al-Zuhaili, al-Fiqh al-Islam wa Adillatuh, Juz VIII, (Damaskus: Dar al-Fikr, 1997), hlm. 122.

${ }^{23}$ Muhammad al-Rahim al-Kisika, al-Miras al-Muqaran, (Baghdad: Dar alFikr, 1997), hlm. 109.

${ }^{24}$ Ramlan Yusuf Rangkuti, Pembaharuan Hukum Islam di Indonesia; Studi tentang Kompilasi Hukum Islam, Disertasi Program Pascasarjana UIN Syarif Hidayatullah Jakarta, 2003, hlm. 260-261. 
pengkhususan kerabat-kerabat yang tidak dapat menerima pusaka kepada cucu-cucu dan pembatasan penerimaan sebesar $1 / 3$ dari harta peninggalan. Ketentuan $1 / 3$ tersebut terdapat dalam hadis $\mathrm{Sa}^{6} \mathrm{ad}$ bin Abī Waqqās. ${ }^{25}$

Selain itu, ketentuan ini didasarkan oleh pendapat Ibnu Hazm dan kaidah syari'ah yang mengatakan bahwa pemegang kekuasaan mempunyai wewenang memerintahkan perkara yang diperbolehkan karena ia berpendapat bahwa hal itu akan membawa kemashlahatan umum, bila penguasa menetapkan demikian maka wajib ditaati. ${ }^{26}$ Pendapat-pedapat tersebut kemudian diikuti oleh murid-murid mereka dan sampai sekarang berkembang di dunia Islam dengan istilah "wasiat wajibah".

Pemahaman tentang status hukum wasiat ini ternyata mengalami perkembangan sepanjang masa, sangat tergantung dari sudut pandang mana yang melihatnya. Ketentuan hukum wasiat ini sangat tergantung juga dengan kondisi dan situasi orang yang melaksanakan wasiat itu.

\section{Analisis Dasar Hukum Konsep Wasiat Wajibah di Indonesia}

Menganalisis suatu konsep atau ketetapan hukum, maka perlu ditelusuri bangunan konsep hukum tersebut, dalam hal ini, dasar dari konsep wasiat wajibah di Indonesia diambil dari ketetapan pasal 209 KHI setelah mengetahui dasar dari KHI secara global. Sebagaimana penjelasan latar belakang dari ketetapan pasal 209. Adapun dasar ketetapan KHI adalah:

1. Hukum Islam dari berbagai bentuk sebagai sumber utama, seperti: al-Qur'an, as-Sunnah, kitab-kitab fiqih yang berjumlah 38, wawancara ulama, yurisprudensi dan studi banding.

636.

${ }^{25}$ Lihat Al-Imām Abū al-Ḥusain Muslim Ibn al-Hajjāj, Șahīh Muslim, hlm.

${ }^{26}$ Fatchur Rahman, Fiqih Waris, (Bandung: PT. Al-Ma'arif, 1975), hlm. 63. 
2. Peraturan perundang-undangan sebagai sumber legislasi, seperti mengenai perkawinan didasarkan pada UU No. 22/1946 jo. UU No. 32/ 1954 dan UU No. 1/1974 jo. Peraturan pemerintah No. 9 tahun 1975. Sedangkan yang berhubungan dengan bidang kewarisan tidak ditemukan peraturan-peraturan perundang-undangan yang dijadikan rujukan.

3. Hukum adat dan hukum barar yang diadaptasi dan dimodifikasi. ${ }^{27}$

Dasar ketetapan KHI di atas hubungannya dengan pasal 209 KHI adalah: Pertama, hubungannya dengan hukum Islam dalam hal ini adalah kitab-kitab fiqih yang menjadi referensi KHI. Dari beberapa kitab referensi KHI tersebut terdapat beberapa kitab khusus yang menjelaskan tentang wasiat wajibah, baik dari mereka yang setuju dengan adanya wasiat wajibah maupun yang tidak sependapat dengan wasiat wajibah. Kitab-kitab tersebut ialah:

a. Kitab Fiqih Hanafi

Di dalam kitab fiqih hanafi, seperti kitab Badai' alSanai', menjelaskan bahwa wasiat wajibah hanya dilaksanakan sebelum ayat mawaris turun yakni diberikan kepada orang tua dan kerabat. setelah diturunkannya ayat mawaris kewajibannya dihapuskan. ${ }^{28}$

b. Kitab Fiqih Maliki

Dalam kitab Muwatto' menjelaskan bahwa kewajiban berwasiat kepada ahli waris sebagaimana penjelasan dari ayat 180 surat al-Baqarah adalah sudah dihapus hukumnya dengan turunnya ayat mawaris dan hadis nabi yang melarang memberi wasiat kepada ahli waris kecuali mendapat izin dari ahli waris yang ada (لا تجوز لوارث وصية إلا أن يجيزه الورثه).

${ }^{27}$ Cik hasan Bisri, Kompilasi Hukum Islam ....., hlm. 10-11.

${ }^{28}$ Alauddin Abu bakar, Badai' al-Sanai', Juz VII, (Bairut, Dar al-Kitab al'Arobi, 1974), hlm. 330-1. 1985), hlm. 765 .

${ }^{29}$ Malik bin Anas, Muwatto' al-Imam Malik, (Bairut, Dar Ihya' at-Turas, 
c. Kitab Fiqih Syafi'i

Dalam kitab Imam Syafi'i, seperti al-Umm, menganggap bahwa kewajiban berwasiat sebagaimana penjelasan ayat 180 surat al- al-Baqarah adalah sudah dihapus semenjak turun ayat mawaris dan dikuatkan oleh hadis Nabi tidak ada wasiat kepada ahli waris (لا وصية لوارث). Menurut Imam Syafi'i tidak membolehkan berwasiat kepada ahli waris yang mendapatkan harta waris dan membolehkan (tidak mewajibkan) berwasiat kepada selain ahli waris. ${ }^{30}$

Selain itu, dalam kitab lain seperti kitab Hasiyyah asSyarqawy oleh Hasiyah al-Qalyubi dan al-Umairah menjelaskan bahwa kewajiban wasiat hanya sebelum ayat mawaris turun. Setelah turunnya ayat mawaris, kewajiban tersebut sudah tidak berlaku lagi. Akan tetapi berwasiat kepada ahli waris yang tidak mendapatkan warisan adalah lebih utama juga kepada mahram yang ada hubungan nasab, susuan, keluarga sebab adanya perkawinan, perwalian dan tetangga. ${ }^{31}$

d. Kitab Fiqih Hambali

Kitab fiqih hambali seperti al-Mugni karya Ibn Qudamah menjelaskan bahwa wasiat adalah hak seseorang yang mempunyai harta yang banyak maupun sedikit. Menurut Abu Bakar 'Abdul Aziz yang mengambil pendapatnya Daud dari Masruq dan Towu>s bahwa wasiat hukumnya wajib bagi kerabat yang tidak menerima harta warisan. ${ }^{32}$

e. Kitab Fiqih Muqaran (perbandingan)

${ }^{30}$ Muhammad bin Idris as-Syafi'i, Al-Umm, Juz IV, (Bairut, Dar al-Fikr, 1983), hlm. 103-4.

${ }^{31}$ Syihabuddin Ahmad Al-Qaliubi dan Syihabuddin Ahmad Al-Umairah, Hasyiyyatani al Qaliubi wa al-Umairah, (Kairo: al-Maktabah at-taufiqiyyah, 2008), hlm. 589.

${ }^{32}$ Abdullah bin Ahmad bin Muhammad bin Qudamah, al-Mughni, Juz VIII, (Ar-Riyad: Dar al-Alim al-Kutub, 1997), hlm. 391. 
Dalam kitab-kitab fiqih muqaran, misalnya kitab Fiqh as-Sunnah, menerangkan bahwa permasalahan di dalam wasiat wajibah dalam pelaksanaannya memiliki hubungan dengan kewarisan, di mana wasiat wajibah diberikan kepada cucu yang ketika ayahnya meninggal terlebih dahulu atau bersamaan dengan pewasiat (kakeknya). Adapun pembagiannya adalah dengan pertimbangan bagian anak lakilaki adalah dua kali lebih besar dari bagian anak perempuan. Setelah wasiat wajibah dipenuhi barulah sisa harta tersebut dibagikan kepada ahli waris yang ada. ${ }^{33}$

Selain kitab-kitab di atas, kitab al-Muhalla karya Ibnu Hazm menjelaskan secara gamblang bahwa wasiat hukumnya wajib dikecualikan bagi orang tua dan kerabat yang sudah menerima harta waris. bagi mereka (orang tua dan kerabat) yang tidak menerima harta waris maka tetap wajib hukumnya memberi wasiat karena itu adalah hak mereka, jika tidak memberinya wasiat (wajibah) maka ia telah mendzoliminya. ${ }^{34}$

Dari uraian beberapa kitab referensi KHI di atas, dapat diambil kesimpulan bahwa sebagian mufassirin atau mujtahidin menganggap QS. al- al-Baqarah [2]: 180 masih muhkam. Dengan demikian, wasiat wajibah hanya diberikan kepada orang tua atau kerabat yang tidak mendapatkan warisan. Dan kebanyakan mufassirin atau mujtahidin berpendapat ayat tersebut sudah di-nasakh, dalam arti di-tabdil-kan atau dihapuskan, yaitu oleh hadis-hadis Rasulullah yang maksudnya tidak sah berwasiat kepada ahli waris. Dalam hal ini KHI tampaknya memilih pendapat mufassirin atau mujtahid ke dua, seperti termuat dalam pasal 195 ayat (3) yang bebunyi "wasiat kepada ahli waris hanya berlaku bila disetujuhi oleh semua ahli waris". ${ }^{35}$

${ }^{33}$ As-Sayyid Sabiq, Fiqih al-Sunnah, Jilid III, (Kairo: Dar al-Fath li i'lmi al-‘Araby, 1989), hlm. 374.

${ }^{34}$ Ibid., hlm. 353.

${ }^{35}$ Ibid., hlm. 94. 


\section{Implementasi Wasiat Wajibah di Indonesia}

Pemberian wasiat wajibah bagi anak angkat atau orang tua angkat tidak lepas dari praktik pengadopsian anak pada kelompok masyarakat Indonesia yang bebeda-beda antara satu daerah dengan daerah lain. Di Minangkabau misalnya, pengangkatan anak diperbolehkan, tertapi hal itu tidak menimbulkan hubungan kewarisan antara orang tua angkat dengan anak angkatnya. Sementara di daerahdaerah yang menganut sistem kekerabatan bilateral (Parental/keibubapakan) seperti di jawa, sulawesi, dan sebagian kalimantan pengangkatan anak menimbulkan hubungan kewarisan. ${ }^{36}$

Kalangan masyarakat adat jawa, orang tua yang tidak mempunyai anak kandung, maka anak angkat yang berkelakuan baik terhadap orang tua angkat akan mendapatkan harta warisan dari orang tuanya. Jika orang tua selain mempunyai anak kandung juga anak angkat, maka dalam pewarisan anak kandung akan mendapat lebih banyak dari anak angkat, dikarenakan anak angkat masih tetap dapat mewarisi dari orang tua kandungnya. Adat jawa mengenal asas "ngangsu sumur wong loro" yang bermakna bahwa seorang anak angkat memperoleh warisan dari dua sumber yaitu orang tua kandung dan orang tua angkat. ${ }^{37}$

Dengan melihat realitas yang tumbuh dan berkembang di masyarakat Indonesia, menurut Moh. Daud Ali kedudukan anak angkat tetap diletakkan di luar ahli waris, sama dengan yang terdapat dalam kitab-kitab mawaris selama ini. Namun, dengan mengadaptasi nilai hukum adat secara terbatas ke dalam nilai hukum Islam karena beralihnya tanggung jawab orang tua asal kepada orang tua angkat mengenai pemeliharaan kehidupan sehari-hari dan biaya pendidikan berdasarkan putusan pengadilan, seperti yang disebutkan dalam KHI pasal 171 huruf h pada ketentuan umum. Oleh karena itu, lahirlah pasal 209 KHI yaitu "terhadap anak angkat yang tidak menerima

\footnotetext{
${ }^{36}$ Syukri Abu Bakar, “Aplikasi 'Urf.....”, hlm. 90.
}

${ }^{37}$ Hilman Hadikusuma, Hukum Waris Indonesia Menurut Perundangan, Hukum Adat, Hukum Agama Hindu Islam, (Bandung:PT Citra Aditya bakti, 1991), hlm. 117. 
wasiat diberi wasiat wajibah sebanyak-banyaknya sepertiga harta peninggalan orang tua angkatnya". ${ }^{38}$ Selain itu juga melihat hubungan yang sangat akrab antara anak angkat dan orang tua angkat, sehingga merupakan suatu kesatuan keluarga yang utuh yang diikat oleh kasih sayang yang murni secara moral orang tua angkat dituntut memberi wasiat atau hibah sebagian hartanya untuk kesejahteraan anak angkatnya. Demikian pula handaknya anak angkat yang telah mampu dan sejahtera hidupnya, bersikap etis dan manusiawi terhadap orang tua angkatnya dengan memberi wasiat atau hibah untuk kesejahteraan orang tua angkatnya yang telah berjasa membesarkan dan mendidiknya. ${ }^{39}$

Persoalan anak angkat yang menyangkut status, hak dan kewajibannya dalam perspektif hukum Islam tidak dapat dipisahkan dari pengertian adopsi dan praktiknya secara umum di masyarakat, adopsi secara garis besar mempunyai dua pengertian, yaitu: Pertama, mengambil anak orang lain untuk diasuh dan didik dengan penuh perhatian dan kasih sayang, dan diperlukan oleh orang tua angkatnya seperti anaknya sendiri, tanpa memberi status anak kandung kepadanya. Kedua, Mengambil anak orang lain untuk diberi status sebagai anak kandung sehingga ia berhak memakai nasab orang tua angkatnya dan mewarisi harta peninggalannya, dan hak-hak lainnya sebagai hubugan anak dengan orang tua. ${ }^{40}$

Melihat persoalan di atas, KHI memaknai anak angkat seperti pada pengertian yang pertama, yaitu anak angkat tetap anak angkat dan selamanya tidak bisa menjadi anak kandung. Oleh karena itu, sewaktu diadakan wawancara kepada kalangan ulama Indonesia pada saat pengumpulan bahan-bahan KHI, tidak satu ulamapun yang dapat menerima penerapan status anak angkat menjadi ahli waris. Bertitik dari sikap dan reaktif para ulama dimaksud, perumusan KHI merasa

38 Moh. Daud Ali, Hukum Islam dan Peradilan Agama, (Jakarta: PT Raja Grafindo Persada, 1997), hlm. 137-138.

39 Setiawan Budi Utomo, Fiqih Aktual: Jawaban Tuntas Masalah Kontemporer, (Jakarta: Gema Insani Press, 2003), hlm. 3.

${ }^{40}$ Setiawan Budi Utomo, Fiqih Aktual....., hlm. 1. 
sadar bahwa tidak perlu melangkah membelakangi ijma' para Ulama. ${ }^{41}$

Kehadiran KHI lebih bersifat dinamika Islam pada umumnya, Islam Indonesia pada khususnya. Tidaklah Islam Indonesia memiliki hukum sendiri. Biarkan KHI dikualifikasikan sebagai fiqih Indonesia yang tumbuh dan berkembang di bumi Indonesia. Namun suatu hal yang pasti, bahwa kehadiran KHI sebagai fiqih Indonesia tidak pernah mengurangi dan melenyapkan keabadian dan keuniversalan nilai-nilai normatifnya. Sebab nilai-nilai normatif yang terkandung dalam KHI itu sendiri tetap bersifat umum secara fundamental sebagaimana dia diturunkan beberapa abad sebelumnya. ${ }^{42}$ Dengan demikian, KHI merupakan suatu terobosan yang bercirikan budaya Indonesia dan menuju pembentukan hukum di Indonesia.

\section{A. Penutup}

Kompilasi Hukum Islam mempunyai ketentuan tersendiri tentang konsep wasiat wajibah. yaitu membatasi orang yang berhak menerima wasiat wajibah hanya kepada anak angkat dan orang tua angkat saja. Secara garis besar, antara ahli waris pengganti dengan wasiat wajibah adalah sama. Perbedaannya, jika dalam wasiat wajibah dibatasi penerimaannya, sedangkan dalam ahli waris pengganti adalah menggantikan hak sesuai dengan hak yang diterima orang yang digantikan tersebut.

Wasiat wajibah mempunyai titik singgung secara langsung dengan hukum kewarisan Islam, maka pelaksanaannya diserahkan kepada kebijaksanaan hakim dalam menetapkannya dalam proses pemeriksaan perkara waris yang diajukan kepadanya. Dalam memeriksa perkara waris tersebut, para hakim sangat memperhatikan nilai-nilai moral yang hidup dalam masyarakat, karena wasiat wajibah itu mempunyai tujuan untuk mendistribusikan keadilan di Indonesia, yaitu pada umumnya, memberikan bagian kepada orang tua angkat

41 Yahya Harahap, Kedudukan Kewenangan dan Acara Peradilan Agama No. 7 Tahun 1989, edisi II, (Jakarta: Sinar Grafika, 2005), hlm. 48.

${ }^{42}$ Ibid., hlm. 34. 
dan atau anak angkat yang mungkin sudah sangat berjasa kepada si pewaris tetapi tidak diberi bagian dalam ketentuan hukum waris Islam.

\section{Referensi}

'Arabi, Ibn, Ahkam al-Qur'an, Juz I, Bairut: Dar al-Kutub al'Ilmiyyah, 1988.

Ali, Moh. Daud, Hukum Islam dan Peradilan Agama, (Jakarta: PT Raja Grafindo Persada, 1997.

Anas, Malik bin, Muwatto' al-Imam Malik, Bairut, Dar Ihya' atTuras $\{, 1985$.

Bani, Muhammad Nasiruddin Al-, Șahīh Sunan at-Tirmiż̄i, CD, Bab "Wașiat", hadis no: 2210.

Bakar, Alauddin Abu, Badai' al-Sanai', Juz VII, Bairut, Dar al-Kitab al-`Arobi, 1974.

Bakar, Syukri Abu, "Aplikasi 'Urf dalam Kompilasi Hukum Islam", Istinbath: Jurnal Hukum Islam, UIN Mataram, Vol. I, No. 1, Juli-Desember 2003.

Bisri, Cik Hasan, Kompilasi Hukum Islam dan peradilan Agama dalam Sistem Hukum Nasional, Jakarta: Logos Wacana Ilmu, 1999.

Departemen Pendidikan dan Kebudayaan, Karnus Besar Bahasa Indonesia, Cet. 2, Jakarta : Balai Pustaka,1989.

Hadi, Samsul, "Pembatasan Wasiat Sebagai Bentuk Keadilan Hukum Islam", Al-Ahwal: Jurnal Hukum Keluarga Islam, UIN Sunan Kalijaga, Vol. 9, No. 2, Desember 2016 M/1438 H, hlm. 169184.

Hadikusuma, Hilman, Hukum Waris Indonesia Menurut Perundangan, Hukum Adat, Hukum Agama Hindu Islam, Bandung: PT Citra Aditya bakti, 1991.

Hajjāj, Al-Imām Abū al-Ḥusain Muslim Ibn Al-, Șahīh Muslim. 
Harahap, Yahya, Kedudukan Kewenangan dan Acara Peradilan Agama No. 7 Tahun 1989, edisi II, Jakarta: Sinar Grafika, 2005.

JazirI, Abdurrahman Al-, al-Fiqhu 'Ala Mazahib al-Arba'ah, terj. Moh. Zukri, Jilid 4, Semarang: Asy-Syifa', 1994.

Kisika, Muhammad al-Rahim Al-, al-Miras al-Muqaran, Baghdad: Dar al-Fikr, 1997.

Makhluf, Hasanayn Muhammad, al-Mawaris fi al-Syari'ah alIslamiyyah, Mesir: Mathba'ah al-Mudna, 1976.

Pasaribu, Chairumman dan Suhrawardi K. Lubis, Hukum Perjanjian dalam Islam, Jakarta: Sinar Grafika, 1996.

Qaliubi, Syihabuddin Ahmad Al- dan Syihabuddin Ahmad AlUmairah, Hasyiyyatani al Qaliubi wa al-Umairah, Kairo: alMaktabah at-taufiqiyyah, 2008.

Qudamah, Abdullah bin Ahmad bin Muhammad bin, al-Mughni, Juz VIII, Ar-Riyad: Dar al-Alim al-Kutub, 1997.

Rahman, Fatchur, Fiqih Waris, Bandung: PT. Al-Ma'arif, 1975.

Rangkuti, Ramlan Yusuf, Pembaharuan Hukum Islam di Indonesia; Studi tentang Kompilasi Hukum Islam, Disertasi Program Pascasarjana UIN Syarif Hidayatullah Jakarta, 2003.

Rofiq, Ahmad, Hukum Islam di Indonesia, Jakarta; PT RajaGrafindo Persada, 1997.

Sabiq, As-Sayyid, Fiqih al-Sunnah, Jilid III, Kairo: Dar al-Fath li i'lmi al-'Araby, 1989.

Sadzali, Munawir, Peradilan Agama dan Kompilasi Hukum Islam dalam tata hukum Indonesia, Yogyakarta: UII Press, 1993.

Syafi'I, Muhammad bin Idris as- , Al-Umm, Juz IV, Bairut, Da>r alFikr, 1983.

Tim Redaksi Nuansa Aulia, Kompilasi Hukum Islam, Bandung: CV. Nuansa Aulia, 2009. 
Usman, Suparman dan Yusuf Somawinata, Fiqih Mawaris Hukum Kewarisan Islam, Jakarta: Gaya Media Pratama, 1997.

Utomo, Setiawan Budi, Fiqih Aktual: Jawaban Tuntas Masalah Kontemporer, (Jakarta: Gema Insani Press, 2003.

Zuhaili, Wahbah Al-, al-Figh al-Islam wa Adillatuh, Juz VIII, Damaskus: Dar al-Fikr, 1997.

\section{* Dosen Fakultas Syariah Institut Agama Islam Muhammadiyah Kotamobagu}

